\title{
KNOWLEDGE MANAGEMENT: AN OVERVIEW OF RESEARCHTRENDS
}

Burcu KÖR ${ }^{1}$

Meltem MUTLUTÜRK 2
Received Date (Başvuru Tarihi): 27/07/2017

Accepted Date (Kabul Tarihi): 05/10/2017

Published Date (Yayın Tarihi): 20/12/2017

\begin{abstract}
As a young and interdisciplinary field, Knowledge Management (KM) holds a crucial role in scientific research and development of knowledge-intensive economies. This study elaborates on the methods used in previous studies regarding the research trends of KM and their contribution to the discipline by examining the KM literature. The purpose of the study is to determine the current research trends of KM by analysing KM citation classics and examining their characteristics as well as presenting a holistic framework of KM publications from the results of citation analysis. A total of 152 articles published in peer review journals between the years 2010 2014 were analysed. As a result of the analysis, a holistic KM framework was developed in order to contribute to a consensus of KM field. The results of the study reveals that the coverage of KM articles expanded into a broad spectrum of concepts, disciplines and environment.
\end{abstract}

Keywords: Knowledge Management, Knowledge Management Framework, Research Trends

JEL Classification: C100, D800

\section{BÍLGİ YÖNETIMİ: ARAŞTIRMA EĞILIMLERINNE GENEL BAKIŞ}

\section{ÖZ}

Genç ve disiplinlerarası bir alan olan Bilgi Yönetimi (BY), bilimsel araştırmalarda ve bilgiye dayalı ekonomilerin geliştirilmesinde önemli biryere sahiptir. Bu çalışma BY literatürünü dikkatle gözden geçirerek, $B Y$ araştırma ĕgilimlerini içeren çalışmalarda kullanılan yöntemleri ve bunların BY disiplinine katkısını ayrıntılı olarak incelemektedir. Bu çalışmanın amacını, BY atıf klasiklerinin ve bunların temel özelliklerinin incelenmesiyle mevcut $B Y$ araştırma eğilimlerinin ve atıf analizleri sonuçları doğrultusunda bütüncül bir BY çerçevesinin belirlenmesi oluşturmaktadır. Bu çalışmada, 2010 ile 2014 yılla rı arasında akademik hakemli dergilerde yayınlanan 152 makale incelenmiştir. Bu incelemelerin sonucunda, bütüncül bir BY çerçevesi geliştirilerek BY alanında konsensüs oluşturmasına katkı sağlaması hedeflenmektedir. Bu çalışmanın sonuçları, BY makalelerinin kapsamının oldukça geniş kavram, disiplin ve çevreden oluştuğunu göstermektedir.

Anahtar Kelimeler: Bilgi Yönetimi, Bilgi Yönetimi Çerçevesi, Araştırma Ĕ̆ilimleri

JEL Sinıflandırması: C00, D800

\footnotetext{
1 Amsterdam Uluslararası İşletme Okulu burcukor@gmail.com

2 Boğaziçi Üniversitesi meltem.mutluturk@ boun.edu.tr
}

orcid.org/0000-0002-5786-6476

orcid.org/0000-0001-5666-594X 


\section{INTRODUCTION}

Research within the field of KMhas consistently grown and received increased attention from researchers and practitioners, especially within the last decade (Dwivedi et al., 2011; Lee and Chen, 2012). Ever since the term KM emerged, a vast range of definitions have arisen. To give an example of this range are a few definitions of KM; Lee and Yang (2000, p. 784) define $\mathrm{KM}$ as "the collection of processes that govern the creation, dissemination and leveraging of knowledge to fulfil organizational objectives". Laudon and Laudon (1998 as cited in Hlupic, Pouloudi and Rzevski, 2002, p.93) state that KM is "the process of systematically and actively managing and leveraging stores of knowledge in an organization". KM is also defined as the utilization of knowledge, to accomplish organizational objectives through the structuring of people, technology and knowledge content (Davenport et al., 1998).

The various definitions indicate that KM has been adopted by a broad-scope of areas (e.g., management information systems, information technology (IT), human resources, strategy, marketing, organizational behavior...) and gives us insight into the many aspects of the discipline (Heisig, 2015). The ambiguity regarding the definition of KM can be interpreted from a management fashion point of view to be an important feature as it allows flexibility of interpretation when establishing new ideas or work areas (Bijker, Hughes and Pinch, 1987). This allows other disciplines and organizations to implement $\mathrm{KM}$ in various ways depending on how they understand the concept (Fteimi, 2015). Studies such as that of Scarbrough and Swan (2001) have been conducted to provide evidence of the growing popularity of KM and its diffusion in terms of the management fashion model.

Abrahamson (1996, p. 257) defines management fashion as being "a relatively transitory belief, disseminated by fashion setters, that management techniques leads to rational management progress". Drawing from Abrahamson's (1996) management fashion theory, a number of studies have given emphasis on knowledge management as being one of the most recent and widespread fashions (Scarbrough, 2002; Scarbrough, Robertson and Swan, 2005).

Abrahamson has perfected the citation analysis method that is the tracking of a particular idea or approach over time in published journal articles. Between the stages of a fashion taking off, reaching maturity and eventually becoming neglected, this method produces classic 'bellshaped curves' of increase and decline (Fincham and Roslender, 2003). Hence, citation analysis can be linked to management fashion as the classic bell-shaped curves are said to be indicative of a management fashion (Hislop, 2010; Clark, 2004). The importance of citation has been recognized by Merton (1998) as ". . . what is surely the most widespread and altogether basic 
form of scholarly recognition, that which comes with having one's work used and explicitly acknowledged by one's peers." (Small, 2004). There has been a rise in the number of studies researching the quality of research papers using citation analysis as an indicator of research quality. In fact, citations between scientific publications are frequently used as quantitative indicators of importance and as surrogates for the impact of the publications within the scientific community. Thus, the more citations a paper has acquired, the more significant it can be considered within its field. Citation analysis is also used as footing for the quantitative interpretation of individual scholars (Hirsch, 2005; Egghe, 2006), journals (Garfield, 2006), universities, institutions (Kinney, 2007) and even countries (Radicchi and Costellano, 2012).

Analysing these publications leads to the recognition of a fast-growing collection of insights concerning various theories, topics or themes (Fteimi and Basten, 2015). Analysing citation classics by identifying the topics, frameworks and methods used in the relevant studies based on KM helps us yield the necessary information to make a decision regarding where $\mathrm{KM}$ is going as a discipline. According to Serenko and Dumay (2015a), the KM discipline is at the pre-science stage but has been gradually progressing towards academic maturity. Drawing from their argument that in an established and advanced field, critical works based on empirical evidence should be given more account than normative studies which are based on literature reviews and viewpoints it can be said that should the citation count of empirical citation classic articles be higher than that of normative citation classics the field in question has matured into a normal science. Thus, exploring the methods of KM studies can give us insight into the maturity stage of the field.

The basis of the study is to establish the current research trends of KM and its impact of other topics by analyzing the citation classics between the years of 2010-2014. This study elaborates on the methods used in previous studies of Serenko and Dumay (2015a, 2015b) regarding the research trends of KM and its contribution to the KM discipline. The results presented in this paper can contribute to the theory that KM is maturing into a science from its embryonic state and can additionally contribute to a common understanding of the field by presenting a general framework of KM. Additionally, conducting a review of the existing KM literature and visualisation of current research trends enhance the understanding of currently under-explored themes, theories and methods in the KM field, which further help researchers and/or practitioners to identify potential research topics (Dwivedi et al, 2011). The present study also aims to provide a source for researchers and/or practitioners in the KM field, thereby 
giving insight into the core of the KM domain, the directions for KM future research, as well as the productivity of researchers, journals, institutions and countries.

The rest of the paper is structured as follows: Section 2 focuses on the theoretical background. Subsequently, the methodology, results and a KM framework is presented. In the last section; conclusion, limitations and future works are discussed.

\section{THEORETICAL BACKGROUND}

KM is in nature a multi-disciplinary field (Serenko and Bontis, 2013). This can be seen from the various interpretations of the definition of the term. Some definitions seem to adopt a soft approach while others a hard approach (Giaglis, 2003). The characteristics and differe nces between hard and soft centric approaches are summarized in Table 1. The soft-centric approach recognizes knowledge as a process focusing on people and behavioral issues whereas the hardcentric approach recognizes knowledge as a tool using a more IT and engineering focus (Serenko and Dumay, 2015b). Quintas et al., (1997) defines KM as "the process of critically managing knowledge to meet existing needs, to identify and exploit existing and acquired knowledge assets and to develop new opportunities." This definition, along with that of Taylor (1997) and De Jarnet (1996) highlight the importance of 'soft' issues as opposed to Malhotra (1998), Bassi (1997) and Frappaulo and Toms (1997) who highlight the importance of technology or 'hard' issues (Hlupic, Pouloudi and Rzevski, 2002). Frappaulo and Toms (1997) definition of KM being "a tool set for the automation of deductive or inherent relationships between information objects, users and processes", can be used as an example of a 'hard' issue definition.

Table 1: Different Research Approaches

\begin{tabular}{lll}
\hline & Hard-Centric & Soft-Centric \\
Driven by & Technological Developments & Organisational Problems \\
Focus on & Information & Process \\
Reference & Computer Science, Information & Management Science, Cognitive \\
Disciplines & Systems, Artificial Intelligence & Sciences, Psychology, Linguistics \\
Exemplary & Knowledge Management & Collaborative Work Processes \\
Outcomes & Systems, Knowledge Ontologies & Employee Empowerment Mechanisms \\
\hline
\end{tabular}

Note: Reprinted from "Directions and trends in knowledge management research: Results from an empirical analysis of European projects," by Giaglis, G. M., 2003, In Knowledge and Business Process Management, p.5, IGI Global.

The basis of many studies regarding KM have been to produce evidence regarding the debate of whether $\mathrm{KM}$ is a slowly maturing towards becoming a reference discipline (Serenko and Bontis, 2013). A reference discipline is defined as a deep-rooted scholarly field that 
provides theoretical and methodological foundations for other disciplines (Nambisan, 2003). If $\mathrm{KM}$ is in fact maturing into a reference discipline, it is crucial to study its current position within the academic community. This can be achieved by way of citation analysis as have many studies before this used in order to measure the impact of the works of scholars within the knowledge domain, visualise growth and identify inter-disciplinary relationships (Lee and Chen, 2012). Citation analysis is also known as the method of tracking a particular idea or approach over a certain period in published journal articles. This method produces a classic "bell-shaped curve" which is known to be an indicator of management fashion (Clark, 2004; Hislop, 2010; Van Rossem and Van Veen, 2011). The bell-shaped curve shows us the increase and the decline between the phases of a fashion taking off, reaching maturity and over time becoming neglected (Fincham and Roslender, 2003). Merton (1998, p.620) has recognised the importance of citation as "... what is surely the most widespread and altogether basic form of scholarly recognition, that which comes with having one's work used and explicitly acknowledged by one's peers." (as cited in Small, 2004).

There has been a rise in the number of studies evaluating the quality of research papers using citation analysis, one of the many bibliometric and scientometric methods, as a quality indicator. In fact, citations between scientific publications are often used as not only quantitative indicators of importance but also proxies for the impact of the publications within the scientific community. Hence, the more citations a paper has acquired, the more compelling it can be considered within its field. Citation analysis is also used as a foothold for the quantitative interpretation of scholars (Hirsh, 2005; Egghe, 2006), journals (Garfield, 2006), universities, institutions (Kinney, 2007) and even countries (Radicchi and Costellano, 2012). Scientometric methods are most useful for providing a comprehensive perspective on not only the growth of the collective scholarly knowledge but also the collective and individual productivity of any given field. Bibliometric indicators along with these methods can be used in order to represent how authors perceive a certain domain and its overall structure as well as the popularity of particular authors, publications and sources (Leydesdorff, 1989; Coursaris and Van Osch, 2014). Bibliometric methods provide descriptive observations along four dimensions of measurement (Narin, Olivastro, and Stevens, 1994): (1) Scientific activity article counts to demonstrate the productivity amount of a certain research field; (2) knowledge transfer - implying that the citation process mirrors the link of knowledge within the scientific community and offers an indirect measure of research quality; (3) linkage - evaluation of links between individuals and research fields to illustrate the social and cognitive networks of 
scientific research; (4) citation analysis - as an intermediary for at least one dimension of the quality of a scientific product. Therefore, the use of quantitative methods can give us an insight into the current state and core of the KM domain. The analysis of publications leads to the admission of a developing collection of observations concerning various theories, topics or themes (Fteimi and Basten, 2015). Analysing citation classics by identifying the topics, frameworks and methods used in relevant studies based on KM helps us obtain the necessary information in order to come to a conclusion regarding the path of KM as a discipline.

The term citation classics was first proposed by Garfield (1977) and defined as 'studies within a discipline that have been cited most frequently'. Citation classics, stemming from citation counts can be used to contribute to an individual scholar's reputation and to evaluate them for hiring, promotion, grants etc. (Safer and Tang, 2009). Citation classics are the foundation of a field. Therefore, they help establish a future area of research regarding a topic or topics based on a field. Citation classics are often analyzed in order to obtain information regarding attributes of the cited works. Graduate students, fellow scholars may use these lists to guide them on a relevant field to study in or areas that are in need of research by familiarising them with the most popular works and authors of any given field. Citation classics can help boost national citation indicators promoting authors and in turn help in the development of international works. Taking these factors into account, citation classics allow researchers to measure the relative impact of their work on their chosen discipline (Serenko and Dumay, 2015a).

The use of metrics and indices in the evaluation of research has become an intrinsic part of academia (Harzing and Alakangas, 2016). A large amount of research is carried out by authors from different fields. Evalution can be done to establish the quality of research produced by a group of authors, but sometimes evaluation needs to be done to generate the quality of a single author's research. The quality of research is commonly assessed in terms of ranking parameters which are based on number of citations (Alguliyev et.al., 2015).

The Hirsch index (Hirsch, 2005) is among the most popular of citation indices. A scholar has an index of $\mathrm{h}$ if $\mathrm{h}$ of their $\mathrm{N}$ papers has received at least $\mathrm{h}$ citations each and the remaining papers have received no more than $\mathrm{h}$ citations each. This index has many advantages such as it is simple to calculate and takes into account both the quantity and the quality of a scholar's work (Alguliyev et al., 2015). Reviews of the various indexes that have stemmed from the hindex have shown that hardly any offer significantly different information such as that of Bornmann et. al. (2011). The research of Sidiropoulos et.al (2007) claims that due to the fact 
that researchers do not publish the same amount of work, the original h-index is not a fair enough metric. In 2007, Harzing and Alakangas (2016) introduced the hI,norm through the Publish and Perish program. This index first normalizes the citations for each paper by dividing the number of citations by the number of authors and calculates the h-index of the normalized citation counts. This index accurately accounts for co-authorship effects.

The focus of this study lies on discovering current trends of KM and to establish its place on the path to becoming a normal science and consequently presenting a general framework of KM in order to contribute to a consensus of the subject matter. Many studies have been concluded in order to map the current path KM is taking and how it is being interpreted by other disciplines. Studies using various methods and approaches to reach a general understanding of the KM concept have been conducted most of which have stemmed from lack of a taxonomy regarding the subject. The most common method is to use citation classics which shed light on the citation behaviour of scholars to better understand the topics KM references and whether it has endured over the years or can be deemed a fad.

\section{METHODOLOGY}

In line with Abrahamson's management fashion theory, bibliographic and citation analyses were used to model the relative strength and duration of fashion waves in KM research and practice (Van Rossem and Van Veen, 2011). These analyses were employed as a means of categorizing the acquired knowledge. To elaborate on Serenko and Dumay's previous study of citation classics, 152 articles were obtained from both KM and non-KM centric peer review journals between the years 2010-2014 as of November, 2016. KM being a multidisciplinary field drawing from many subject areas (Girard and Girard, 2015) is the reasoning behind the selection of articles from non-KM centric journals as well as KM centric along with peer review journals being acknowledged as having high credibility, acceptance and impact on author's careers (Serenko and Bontis, 2013). Aside from their analysis of these trends performed by using only KM centric journals, this study has added non-KM centric journals to the analysis based on the fact that KM is interdisciplinary and can be found in various journal subject categories such as computer science and decision sciences among others.

The citation data used in this study was obtained from Google Scholar as of November 11, 2016 by using Harzing's Publish or Perish software. Due to the existence of erroneous or duplicate data within Google Scholar, the dataset was revisited and necessary adjustments were made. $20 \%$ of the analysed articles where doubled checked and all articles where read entirely. 
Authors that had a name using non-english characters were checked to see if they were written differently and therefore retrieved twice.

The Normalised h-index (hi,norm) was used to cut off the articles at a specific count (43). The use of the normalised h-index rather than the h-index emerged from the the hi,norm being able to accurately account for the effects of co-authorship. The importance of the effects of co-authorship being taken into account can be understood distinctly after examining the results of this study.

The main reason for researching citation classics is to understand potential scientific obsolescence. Obsolescence can be defined as the decline in an academic article's significance, relevance over a certain amount of time measured using a longitudinal frequency distribution of citations (Serenko and Dumay, 2015b). The main principles of obsolescence are; firstly that with time, all scientific publications will eventually lose impact. The publication will become a source for new studies but gradually it's rate of use will decrease until it reaches zero. Thus, the number of citations will also decline along with it. Lastly, the publication's half-life can be calculated when the number of years (t) the publication took to receive half of its total citation count is established from the time of publication (t0) to the time of analysis (tn) (Bayram, 1998).

The time-frame Nakamoto (1988) introduced suggesting that a scientific article can only maintain its significance for an average 4 years was the footing for choosing the time period for this study. Based on this, the average half-life and the citation peak of an article is two years, after which the citation frequency will decline. (Nakamoto, 1988; Bayram, 1998).

\section{RESULTS}

In order to identify the attributes of KM citation classics such as major publications, articles by year, research methods used, article theme, theories applied and scholars, citation data analysis was conducted and the below results were revealed.

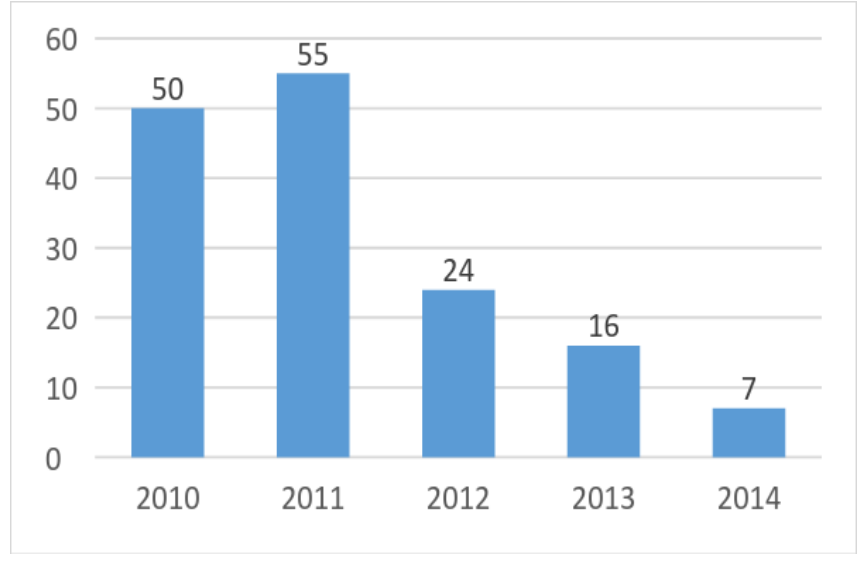

Figure 1: Articles by Year 
As can be seen in Figure 1, the number of publication declines significantly after the year 2011, the reason being that the minimum cut-off citation count was 43 and older articles have a longer period to be cited (Kör, in press). Despite the shorter time period, articles published after 2011 have gained significant citations (almost $31 \%$ of the entire sample). The results presented in Table 2 depict the research methods used in the articles. 21 studies used multiple research methods; hence the total exceeds 152. As can be seen from Table 2, survey is the most prevalent research method, followed by literature reviews and case studies. When compared to the previous analysis of Serenko and Dumay (2015a), it is evident that there is a significant rise in the use of surveys as a research method between the years 2010-2014. The number of articles that are neither empirical nor present literature backing displaying the author's point of view known as viewpoints, has decreased significantly compared to the analysis before 2010. The survey method which is empirical as opposed to normative research, represents the majority of the citation classics.

Table 2: Research Methods Used

\begin{tabular}{lc}
\hline Method & No. of Article \\
\hline Survey/Questionnaire & 73 \\
Literature review (work is based on existing literature) & 33 \\
Case study & 26 \\
Interview & 18 \\
Data mining & 16 \\
Conceptual framework & 10 \\
Other qualitative (epistemology, focus group, etnography, & 7 \\
examination of texts or documents) & \\
Theoretical framework & 5 \\
Exploratory & 5 \\
Modelling tools(an analytical or descriptive tool/model for & 5 \\
the phenomena under investigation) & \\
Experiments & 3 \\
Observation & 3 \\
Viewpoint & 3 \\
Action research & 1 \\
Total & 208 \\
\hline
\end{tabular}

The results presented in Figure 2 reveal the steady increase in the use of empirical research methods between the years 2013 - 2014 over normative research methods. Therefore, we can come to the conclusion that $\mathrm{KM}$ is shifting from theoretical development to the practice stage (Bedford and Lewis, 2015). 


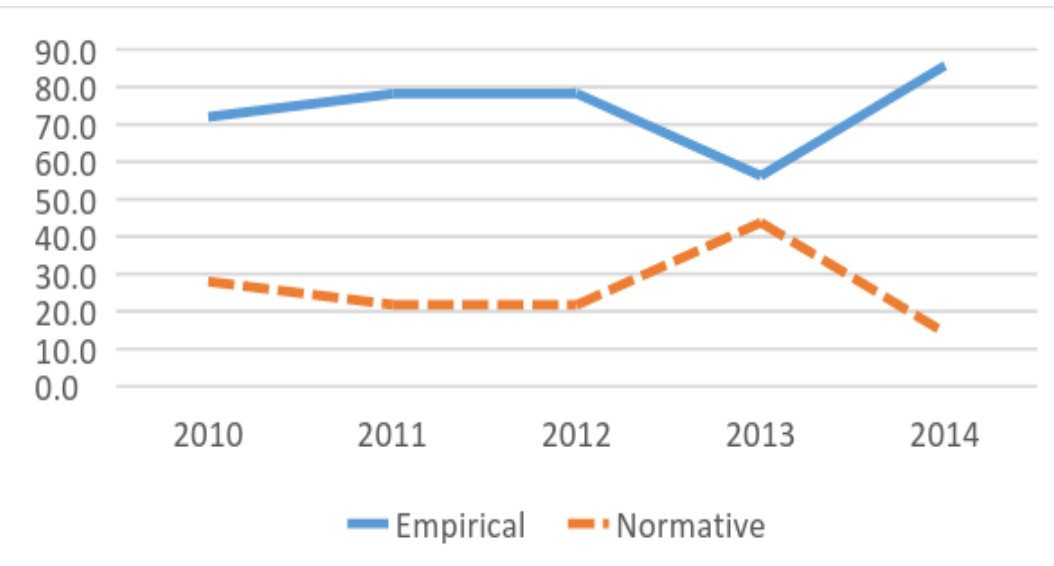

Figure 2: Empirical Versus Normative Citation Classics in KM

Figure 3 examines the theories applied within the analysed articles. This category is relevant to our main goal of determining the stage of maturity of KM by establishing whether the majority of articles applied existing theories or were atheoreatical (Serenko and Dumay, 2015a). The majority of articles used no existing theories. Other dominant theories include resource-based view, knowledge-based view and organizational knowledge creation (or dynamic theory of organizational knowledge creation) which depends on the works of Nonaka (1994), Nonaka and Takeuchi (1995) and Nonaka and Von Krogh (2009) are the dominant theories. These theories are followed by various theories of economy (e.g.,economic theory, microeconomic theory, social and economic theory, theory of economics and information, endogenous growth theory) and various theories of innovation (e.g., diffusion of innovations theory, theory of disruptive innovation, system of innovation theory).

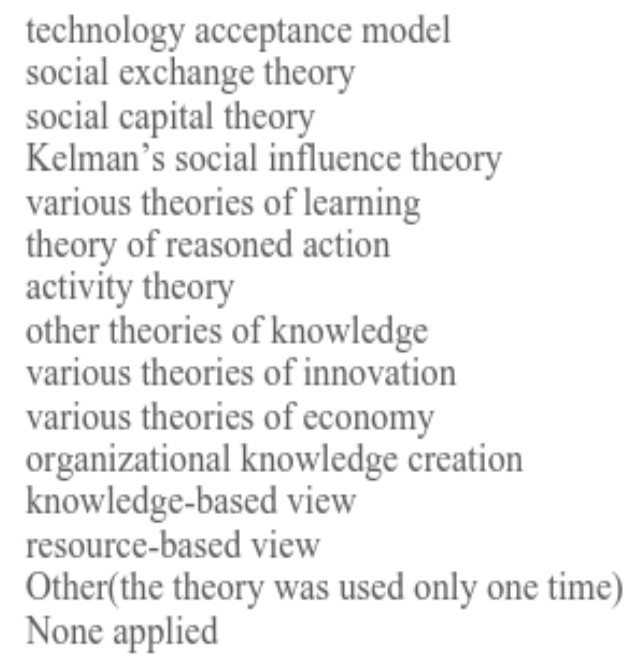

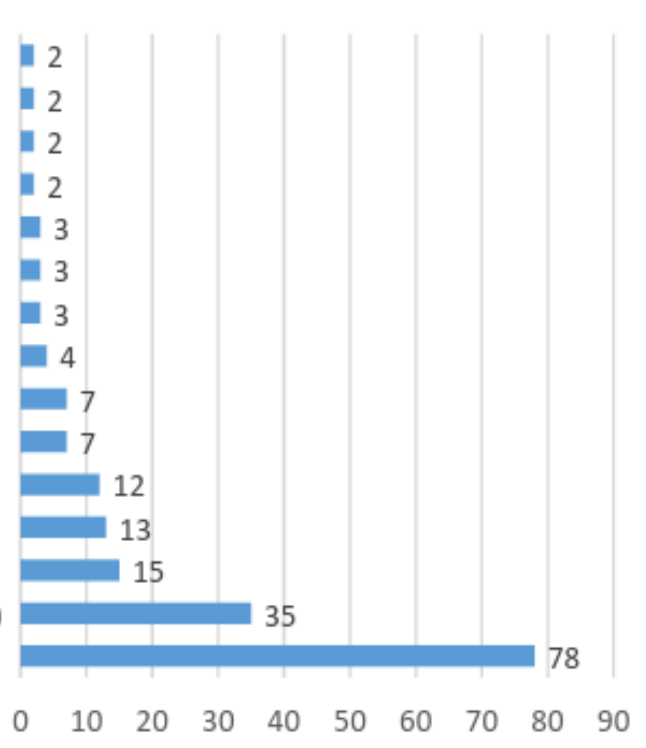

Figure 3: Theories Applied 
Table 3 shows the top journals the analysed articles are published in and their counts. This in turn gives us the distribution of KM within various topics such as computer science and decision sciences. The area/type of journals for the grouping of KM/Intellectual Capital(IC) was established based on the works of Serenko et al., (2010) and Serenko and Bontis (2013). The remaining types or categories were established by reviewing the subject area and category in the Schimago Journal \& Country rank.

Table 3: Top Journals Count

\begin{tabular}{lll}
\hline Journal Name & Count & Subject Area/Category \\
\hline Journal of Knowledge Management & 28 & KM/IC \\
Expert Systems with Applications & 10 & Computer Science -Engineering \\
International Journal of Information Management & 7 & Computer Science \\
Journal of Business Res earch & 4 & Business, Management and Accounting \\
Applied Soft Computing & 3 & Computer Science \\
Computers \& Education & 3 & Computer Science -Social Sciences \\
Computers in Human Behavior & 3 & Computer Science \\
Journal of Strategic Information Systems & 3 & Computer Science - Decision Sciences \\
VINE: The Journal of Information and Knowledge & 3 & KM/IC \\
Management Systems & 2 & Computer Science \\
Advanced Engineering Informatics & 2 & Engineering \\
Automation in Construction & 2 & Computer Science - Decision Sciences \\
Decision Support Systems & 2 & Engineering \\
IEEE Transactions on Engineering Management & 2 & Business, Management and Accounting \\
International Journal of Project Management & 2 & KM/IC \\
Knowledge and Process Management & 2 & KM/IC \\
Knowledge-Based Systems & 2 & KM/IC \\
The Learning Organization &
\end{tabular}

Table 4 presents the authors who have contributed the most to the area in question.

Table 4: Top KM Classics Authors

\begin{tabular}{lc}
\hline Name & No. of Article \\
\hline Ming-Lang Tseng & 3 \\
Alexander Serenko & 2 \\
Bradley N. Doebbeling & 2 \\
Fa'tima Guadamillas & 2 \\
Gary Bastin & 2 \\
Gary N. McLean & 2 \\
George O. Allen & 2 \\
H. Bigas & 2 \\
I-Chieh Hsu & 2 \\
Maria R. Lee & 2 \\
Ming Li & 2 \\
Nick Bontis & 2 \\
Patricia Ordóñez de Pablos & 2 \\
Rajiv Sabherwal & 2 \\
Shu-Hui Chuang & 2 \\
Susanne Durst & 2 \\
\hline
\end{tabular}




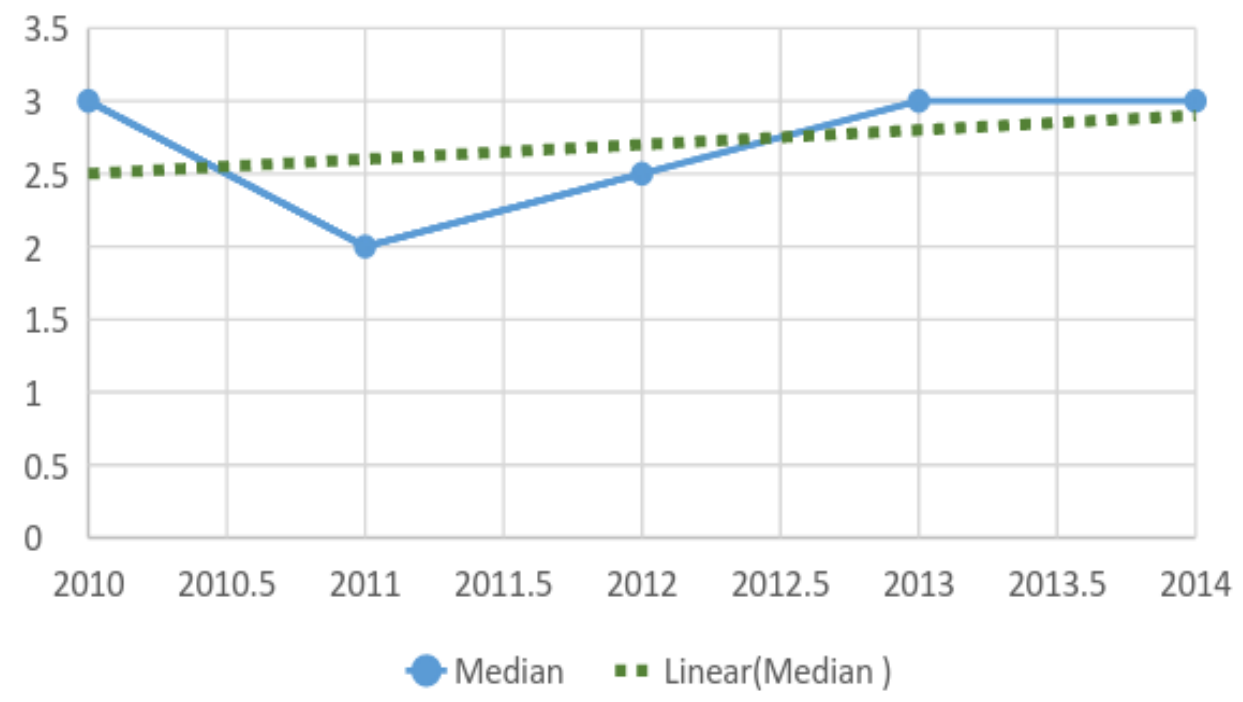

Figure 4: Median Number of Authors per Article

Ming-Lang Tseng has contributed the most to KM within the years 2010-2014, having published three papers. A longitudinal authorship pattern analysis is shown in Figure 4. The results show that after a decline of number of authors per article between the year 2010-2011, a gradual trend toward multi-authored works has begun (see Fig.4).

As with Serenko and Dumay (2015a), an equal credit method was used to calculate institutional and country productivity by which each institution/country receives the score $1 / \mathrm{N}$, $\mathrm{N}$ being the number of authors. The equal credit method is favoured due to its simplicity along with producing highly comparable results (Serenko and Dumay, 2015a). There was a total of 257 different organisations, 36 of which are practitioners (e.g., Deutsche Bundesbank, Dell, Korea Information System Consulting and Audit, Naples Municipality, Partner Healthcare System,...). Additionally, articles were classified based on the country of origin of the author as can be seen in Figure 5.

Based on the calculated scores, the top ten organizations are;

1. Ming-Dao University, Taiwan, (3);

2. Islamic Azad University, Iran, (2.93);

3. Griffith University, Australia, (2.1);

4. University of Castilla-La Mancha, Spain, (2);

5. University of Tehran, Iran, (1.65);

6. Asia University, Taiwan, (1.53);

7. University of the West Indies, Jamaika, (1.50);

8. University of Liechtenstein, Liechtenstein, (1.50);

9. University of Limerick, Ireland, (1.45);

10. University Sains Malaysia, Malaysia, (1.33);

11. Tamkang University, Taiwan, (1.33); 
12. University of Valencia, Spain, (1.33) and

13. University of South Africa, Republic of South Africa, (1.33).

Due to the last four organisations (University Sains Malaysia, Tamkang University, University of Valencia and University of South Africa) having the same score (1.33), they share tenth place.

Contrary to the study of Serenko and Dumay (2015a) where developing countries were non-existent, the majority of citation classics authors are located in Taiwan. Taiwan along with the USA account for $30 \%$ of citation classics authors. Other developing countries such as Iran and India also take place on the list of highest scoring KM publications.

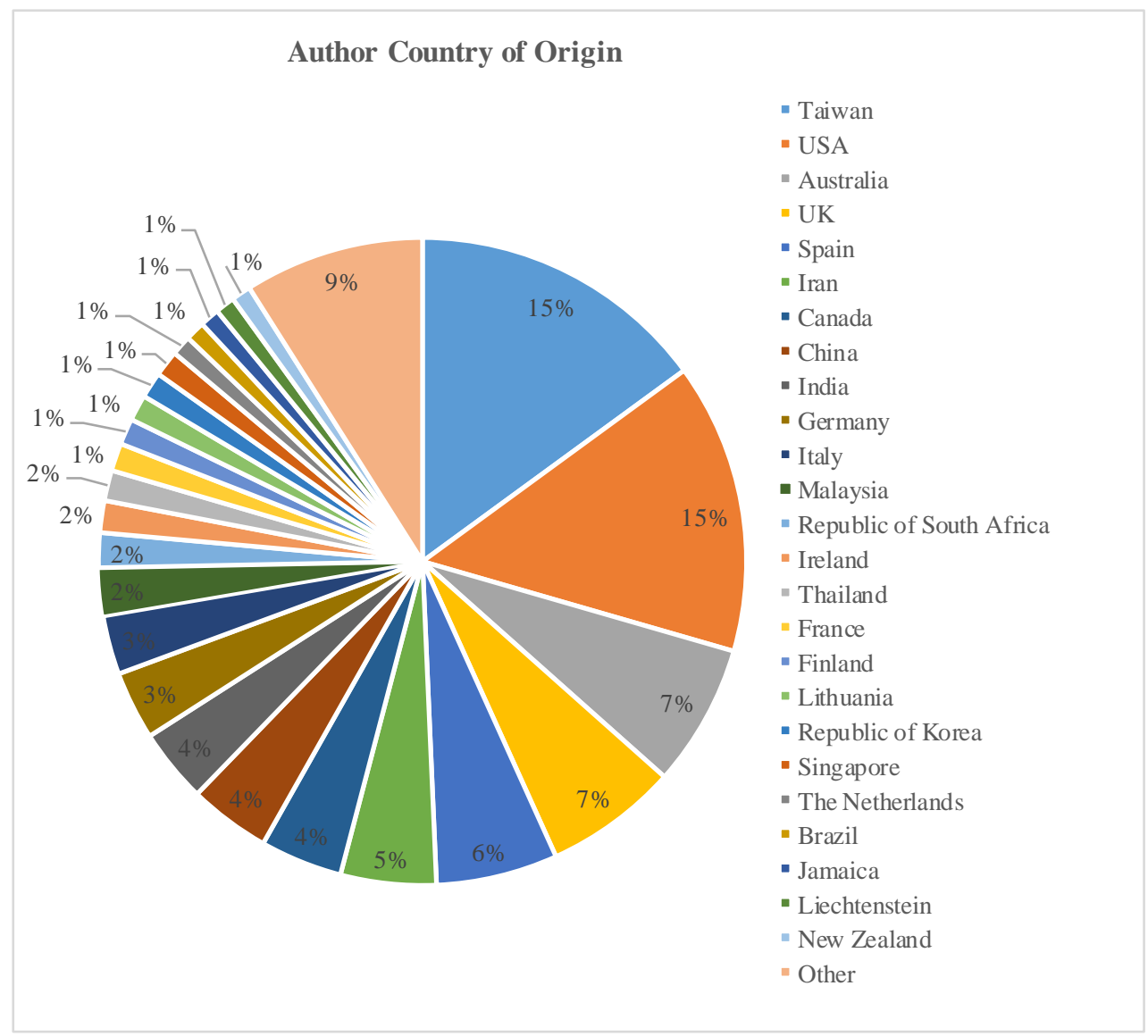

Figure 5: Author Country of Origin

The keywords associated with each article were examined to explore a more detailed level of research topics (Romano and Fjermestad, 2002). Kevork and Vrechopoulos (2009, p. 61) stated that topics should be predetermined and dependent on what the authors themselves have decided indirectly through the keywords of their articles rather than an interpretation.

Figure 6 presents the most popular individual keywords. The list of individual keywords was examined from 152 papers and 644 keywords were found. Firstly, the keyword dataset was purified from evident overlaps and redundancies. For instance: singular and plural forms of the 
same word (e.g. system and systems), two ways to express the same issue (e.g. IT and information technology), two language versions of the same keyword (e.g. organisation and organization), and two or more ways to present the same keyword (e.g. organization culture, organizational culture, or data mining and datamining). Additionally, the keyword "knowledge management" was removed as it is the original search words for the articles. After this, the keyword dataset included 537 keywords and 388 unique keywords. Keyword analysis showed that IT, KMS and organizational learning were used most frequently.
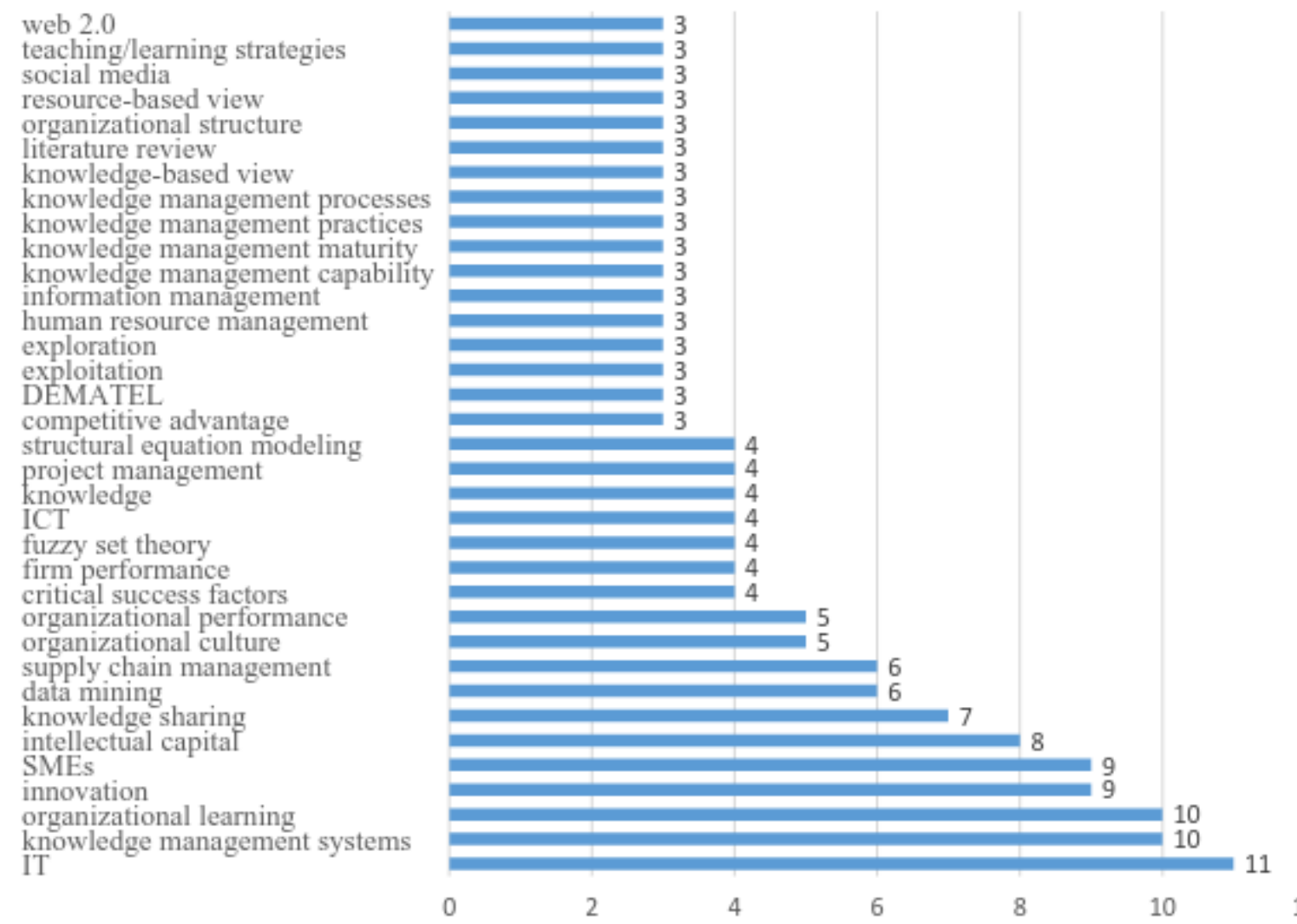

Figure 6: Distribution of the Top 35 Keywords with Their Frequency Counts

\subsection{KM Framework}

Frameworks define the relevant objects and their consistency as well as providing a structure for aspects that have to be considered (Pawlowski and Bick, 2015) during the normative and empirical views of KM. They also provide an outline to the different circumstantial aspects, impact factors as well as outcomes (Pawlowski and Bick, 2015). The framework gives a summary of research design, method and data analysis (based on Fteimi, 2015), KM activities/process capabilities (based on Sandhawalia and Dalcher, 2011; Seleim and Khalil, 2011; Mishra and Uday Bhaskar, 2011), KM results/outcomes (based on Chauvel 
and Despres, 2002; Fteimi, 2015), theories applied in KM publications (Tzortzaki and Mihiotis, 2014; Fteimi, 2015), KM environment/stakeholders (based on Serenko, 2013; Pawlowski and Bick, 2015; Fteimi, 2015) and KM reference disciplines (based on Fteimi, 2015). In addition, this study introduces a KM framework drawing upon Linstone's (1984, 1999) multipleperspectives approach integrating the technical, organizational and personal perspectives which form the heart of the framework. The technical perspective (T) reflects the scientific method as found in science and engineering and takes a rational approach to problem-solving (Mitroff and Linstone, 1993). "The organizational (O) and personal (P) perspectives reflect the respective subjective views of the groups and individuals involved (Turpin, Phahlamohlaka and Marais, 2009, p.28)." The perspectives and categories were assembled from various works and were filled with the literature review, keyword and topic dataset resulting from this study. 


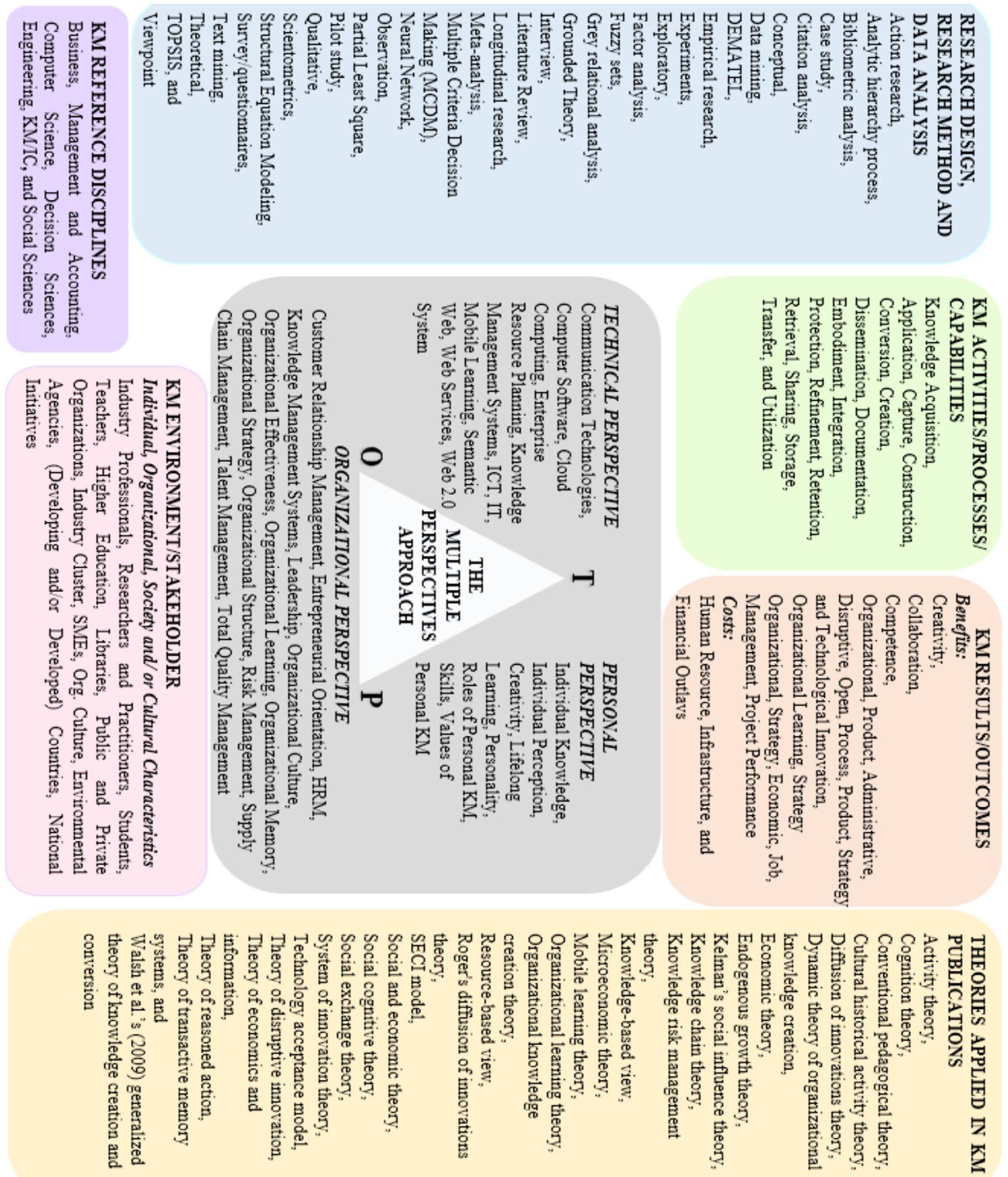

Figure 7: The KM classification framework 


\section{CONCLUSION AND IMPLICATIONS FOR FURTHER RESEARCH}

One of the purposes of this study was to determine the stage of KM within the developmental life-cycle of a discipline (Serenko and Dumay, 2015a) by analysing KM citation classics and examining their characteristics as well as presenting a holistic framework of KM publications. The study was carried out by essentially obtaining the most cited 152 articles from $\mathrm{KM}$ and non-KM centric journals according to Google Scholar using Harzing's Publish and Perish software.

The results presented in this article have several important implications. Within the findings of this study, it can be said that $\mathrm{KM}$ is progressively maturing into a normal science. The term progressively is used to underline the fact that while some findings point towards maturity, others let us conclude that the KM discipline is still evolving. The studies of Serenko and Dumay (2015b) and Bedford and Lewis (2015) support this claim. Indicators that point to maturity within the results are: the increase in co-authored articles, the addition of new topics (e.g., social network, mobile learning, e-learning, distance education), the existence of developing countries within citation classic authors and $\mathrm{KM}$ based article appearing in non-KM centric journals.

It can be inferred that $\mathrm{KM}$ is progressing towards maturity due to the fact that articles based on empirical studies have drawn more attention than normative studies as is the case in well-established scholarly fields according to Serenko and Dumay (2015b). The increase in empirical studies gives us a sense that KM may progressing towards maturity compared to the years before 2010 where normative studies were the majority. Although seemingly heading to the right direction, KM still has a way to go in regards to becoming an advanced scholarly discipline. The lack of the superstar effect also known as the Matthew effect which is the occurrence of a disproportionate distribution of citations among a small percentage of scholars or organisations who produce a large amount of works within a field (Serenko and Dumay, 2015a), may allow us to conclude that KM has not yet reached the final stage of maturity.

Prior research has found a positive correlation between the average number of authors per publication and a field's maturity (Lipetz, 1999). Serenko et al. (2010) state that input from multiple scholars is needed in order to improve the quality of a publication and ensure its acceptance due to the increase in competition and the decline in acceptance rates as a discipline matures. The results of this study may support this claim as a trend towards multiple authored works can be seen. Given the results of this study, the conclusion that KM is not a fad, but a clear trend in progress (Tzortzaki and Mihiotis, 2014) can be drawn. 
The mapping of KM studies through bibliographic and citation analyses indicates that the coverage of KM studies has expanded into a broad spectrum of disciplines, concepts, methods and environments. For example, KM has been studied from an individual, organisational, cultural perspective, including researchers, practitioners, students, educational institutions, libraries and countries. KM studies have been published in business, manage ment and accounting, computer science, KM and IC and social science journals, by using various qualitative, quantitative and mix research methods. Using a mix of multiple research methods might provide a more holistic understanding of KM field. The results of bibliometric and citation analyses also demonstrate that $\mathrm{KM}$ might be recognized as a distinct scholarly discipline with growing research, a body of literature and reference disciplines of its own.

This study provides evidence of individual, institutional, country and journal productivity. By the help of these productivity or ranking lists, researchers can identify specific journals for their future studies and demonstrate the quality of their research. Additionally, this study can guide junior researchers or master's and doctoral students in where to search for commonly accepted, popular and rigorous theories, methodologies, and findings, as well as strategically develop their careers through familiarising them with $\mathrm{KM}$ and understanding which countries or institutions show expertise in the KM field (Serenko and Bontis, 2009, Serenko et al., 2010). The results of this study reveal that most of the productive countries and institutions contained both developed and developing countries, and the top productive institution was from developing countries. Hence, it can be proposed that the KM field is realised as a crucial aspect for the competitive advantage of countries, including developed and developing.

The dominant research themes and concepts as well as important or potential topics for future studies in the field of KM can be inferred from the keyword analysis and KM classification framework. Furthermore, the results of the study help to identify the potentially relevant topics in the field of KM that have not yet been considered (Fteimi, 2015).

\section{LIMITATIONS AND FUTURE RESEARCH SCOPE}

As with all studies, there are a few limitations. Therefore, the results should be viewed in light of these limitations. Firstly, the articles examined within this study do not reflect all publication channels. Books, proceedings and professional journal works were excluded. Only works published in peer reviewed journals were taken into account. The second limitation is that only works published in the English language were examined, thus excluding any articles written in other languages. The third limitation is that this study reflects the view of the author 
and their interpretation of the dataset. The other limitation is the narrow time-frame of the study, due to the fact that one of the aims of the study is to update the study of Serenko and Dumay (2015a). Additionally, there is a lack of studies during 2014, due to the minimum cut-off citation count. Lastly, the time-frame of the study was from 2010-2014 because the average half-life and the citation peak of an article is two years. For future research, analysing papers from 2015 and 2016 would give important insight on the KM field. Future research would also benefit from performing a co-citation analysis and mapping the findings along with the topics as well as improving upon the presented framework by extending the research period, in turn acquiring a broader dataset. 


\section{REFERENCES}

Abrahamson, E. (1996). Management fashion. Academy of management review, 21(1), 254-285.

Alguliyev, R., Aliguliyev, R., Fataliyev, T., \& Hasanova, R. (2015). An aggregated index for assessment of the scientific output of researchers. International Journal of Knowledge Management Studies, 6(1), 31-62.

Bassi, L. J. (1997). Harnessing the power of intellectual capital. Training \& Development, 51(12), 25-31.

Bayram, Ö. G. (1998). Atıf verisi (citation data) ve enformetrik yasalar: Türk kütüphanecilik literatüründeki doktora tezleri üzerinde bir uygulama. Türk Kütüphaneciliği,12(1), 21-32.

Bedford, D. A., \& Lewis, J. (2015). Introduction to the Special Issue: Knowledge Management Models and Theories. Journal of Information \& Knowledge Management, 14(04), 1502002.

Bijker, W., \& Hughes, T. P. Trevor Pinch, eds. 1987. The social construction of technological systems.

Bornmann, L., Mutz, R., Hug, S. E., \& Daniel, H. D. (2011). A multilevel meta-analysis of studies reporting correlations between the $\mathrm{h}$ index and 37 different $\mathrm{h}$ index variants. Journal of Informetrics, 5(3), 346-359.

Chauvel, D., \& Despres, C. (2002). A review of survey research in knowledge management: 1997-2001. Journal of knowledge management, 6(3), 207-223.

Clark, T. (2004). The fashion of management fashion: a surge too far?. Organization., 11(2), 297-306.

Coursaris, C. K., \& Van Osch, W. (2014). A scientometric analysis of social media research (20042011). Scientometrics, 101(1), 357-380.

Davenport, T. H., De Long, D. W., \& Beers, M. C. (1998). Successful knowledge management projects. MIT Sloan Management Review, 39(2), 43.

De Jarnett, L (1996). Knowledge the latest thing. Information Strategy, The Executives Journal, 12 (pt 2), 3-5.

Dwivedi, Y. K., Venkitachalam, K., Sharif, A.M., Al-Karaghouli, W., \& Weerakkody, V. (2011). Research trends in knowledge management: Analyzing the past and predicting the future. Information Systems Management, 28(1), 43-56.

Egghe, L. (2006). Theory and practise of the g-index. Scientometrics, 69(1), 131-152.

Fincham, R., \& Roslender, R. (2003). Intellectual capital accounting as management fashion: a review and critique. European accounting review, 12(4), 781-795.

Frappaolo, C., \& Toms, W. (1997). Knowledge Management: from terra incognita to terra firma. The Delphi Group.

Fteimi, N. (2015). Analyzing the Literature on Knowledge Management Frameworks: Towards a Normative Knowledge Management Classification Schema.

Fteimi, N., \& Basten, D. (2015, May). Impact of Dictionaries on Automated Content Analysis -The Use of Compound Concepts in Analysing Knowledge Management Research. In Proceedings of Twenty-Third European Conference on Information Systems (ECIS), Münster, Germany.

Garfield, E. (1977). Introducing citation clas sics-human side of scientific reports.

Garfield, E. (2006). The history and meaning of the journal impact factor. Jama, 295(1), 90-93.

Giaglis, G. M. (2003). Directions and trends in knowledge management research: Results from an empirical analysis of European projects. Knowledge and business process management, 1. 
Girard, J., \& Girard, J. (2015). Defining knowledge management: Toward an applied compendium. Online Journal of Applied Knowledge Management, 3(1), 1-20.

Harzing, A. W., \& Alakangas, S. (2016). Google Scholar, Scopus and the Web of Science: a longitudinal and cross-disciplinary comparis on. Scientometrics, 106(2), 787-804.

Heisig, P. (2009). Harmonisation of knowledge management-comparing $160 \mathrm{KM}$ frameworks around the globe. Journal of knowledge management, 13(4), 4-31.

Hirsch, J. E. (2005). An index to quantify an individual's scientific research output. Proceedings of the National academy of Sciences of the United States of America, 16569-16572.

Hislop,D.(2010).Knowledge management as an ephemeral management fashion?. Journal of Knowledge Management, 14(6), 779-790.

Hlupic, V., Pouloudi, A., \& Rzevski, G. (2002). Towards an integrated approach to knowledge management:'hard','soft'and 'abstract'is sues. Knowledge and Process Management, 9(2), 90-102.

Kevork, E. K., \& Vrechopoulos, A. P. (2009). CRM literature: conceptual and functional insights by keyword analysis. Marketing Intelligence \& Planning, 27(1), 48-85.

Kinney AL (2007) National scientific facilities and their science impact on nonbiomedical research. Proc Natl Acad Sci USA 104: 17943-17947.

Kör, Burcu (in press). Revealing Trends in Knowledge Management Research: From 2010 to 2016, İstanbul Üniversitesi İşletme İktisadı Enstitisü.

Laudon, K. C., \& Laudon, J. P. (1998). Management Information Systems: Nes Approaches to Organization and Technology. Prentice hall.

Lee, C.C. and Yang, J. (2000), "Knowledge value chain”, Journal of Management Development, Vol. 19 No. 9 , pp. 783-94.

Lee, M. R., \& Chen, T. T. (2012). Revealing research themes and trends in knowledge management: From 1995 to 2010. Knowledge-Based Systems, 28, 47-58.

Leydesdorff, L. (1989). The relations between qualitative theory and scientometric methods in science and technology studies: introduction to the topical is sue. Scientometrics, 15(5-6), 333-347.

Linstone, H. A. (1984). Multiple perspectives for decision making; bridging the gap between analysis and action, Elsevier Science Pub. Co., New York

Linstone, H. A. (1999). Decision making for technology executives: using multiple perspectives to improved performance. Artech House on Demand.

Lipetz, B. A. (1999). Aspects of JASIS authorship through five decades. Journal ofthe Association for Information Science and Technology, 50(11), 994.

Malhotra, Y. (1998). Tooks@work: Deciphering the knowledge management hype. The journal for quality and participation, 21(4), 58.

Merton, R. K. (1988), The Matthew effect in science, 2: cumulative advantage and the symbolism of intellectual property. ISIS, 79 (299)

Mishra, B., \& Uday Bhaskar, A. (2011). Knowledge management process in two learning organisations. Journal of Knowledge Management, 15(2), 344-359.

Mitroff, I. I., \& Linstone, H. A. (1993). Unbounded Mind, Oxford University Press: New York. Nakamoto, H. (1988). Synchronous and diachronous citation distribution. 
Nambisan, S. (2003). Information systems as a reference discipline for new product development. Mis Quarterly, $1-18$.

Narin, F., Olivastro, D., \& Stevens, K. A. (1994). Bibliometrics/theory, practice and problems. Evaluation review, 18(1), 65-76.

Nonaka, I. (1994). A dynamic theory of organizational knowledge creation. Organization science, 5(1), 14-37.

Nonaka, I., \& Takeuchi, H. (1995). The knowledge creation company: how Japanese companies create the dynamics of innovation. Oxford University Press. New York, USA, 304.

Nonaka, I., \& Von Krogh, G. (2009). Perspective-tacit knowledge and knowledge conversion: Controversy and advancement in organizational knowledge creation theory. Organization science, 20(3), 635-652.

Pawlowski, J. M., \& Bick, M. (2015). The global knowledge management framework: Towards a theory for knowledge management in globally distributed settings. Leading Issues in Knowledge Management, Volume Two, 2, 134.

Quintas, P., Lefrere, P., \& Jones, G. (1997). Knowledge management: a strategic agenda. Long range planning, 30(3), 385-391.

Radicchi, F., \& Castellano, C. (2012). A reverse engineering approach to the suppression of citation biases reveals universal properties of citation distributions. PLoS One, 7(3).

Romano Jr, N. C., \& Fjermestad, J. (2001). Electronic commerce customer relationship management: An ass es sment of res earch. International Journal of Electronic Commerce, 6(2), 61-113.

Safer, M. A., \& Tang, R. (2009). The psychology of referencing in psychology journal articles. Perspectives on Psychological Science, 4(1), 51-53.

Scarbrough, H. (2002). The role of intermediary groups in shaping management fashion: The case of knowledge management. International Studies of Management \& Organization, 32(4), 87-103.

Scarbrough, H., \& Swan, J. (2001). Explaining the diffusion of knowledge management: the role of fashion. British Journal of Management, 12(1), 3-12.

Scarbrough, H., Robertson, M., \& Swan, J. (2005). Professional media and management fashion: The case of knowledge management. Scandinavian Journal of Management, 21(2), 197-208.

Seleim, A. A., \& Khalil, O. E. (2011). Understanding the knowledge management-intellectual capital relationship: a two-way analysis. Journal of Intellectual Capital, 12(4), 586-614.

Sengupta, I. N. (1992). Bibliometrics, informetrics, scientometrics and librametrics: an overview. Libri, 42(2), 75-98.

Serenko, A., \& Bontis, N. (2009). Global ranking of knowledge management and intellectual capital academic journals. Journal of Knowledge Management, 13(1), 4-15.

Serenko, A., \& Bontis, N. (2013). Global ranking of knowledge management and intellectual capital academic journals: 2013 update. Journal of Knowledge Management, 17(2), 307-326.

Serenko, A., \& Dumay, J. (2015a). Citation classics published in knowledge management journals. Part I: articles and their characteristics. Journal of Knowledge Management, 19(2), 401-431.

Serenko, A., \& Dumay, J. (2015b). Citation classics published in Knowledge Management journals. Part II: studying research trends and discovering the Google Scholar Effect. Journal of Knowledge Management, 19(6), 1335-1355. 
Serenko, A., Bontis, N., Booker, L., Sadeddin, K., \& Hardie, T. (2010). A scientometric analysis of knowledge management and intellectual capital academic literature (1994-2008). Journal of Knowledge Management, 14(1), 3-23.

Sidiropoulos, A., Katsaros, D., \& Manolopoulos, Y. (2007). Generalized Hirsch h-index for disclosing latent facts in citation networks. Scientometrics, 72(2), 253-280.

Singh Sandhawalia, B., \& Dalcher, D. (2011). Developing knowledge management capabilities: a structured approach. Journal of Knowledge Management, 15(2), 313-328.

Small, H. (2004). On the shoulders of Robert Merton: Towards a normative theory of citation. Scientometrics, 60(1), 71-79.

Taylor, K. (1997). Knowledge management and human resources. International Journal of Technology Management, $11(3), 485-491$.

Turpin, M., Phahlamohlaka, J., \& Marais, M. (2009, May). The multiple perspectives approach as a framework to analyze social systems in a developing country context. In Proceedings of the 10th International Conference on Social Implications of Computers in Developing Countries (pp. 26-28).

Tzortzaki, A. M., \& Mihiotis, A. (2014). A review of knowledge management theory and future directions. Knowledge and Process Management, 21(1), 29-41.

Van Rossem, A., \& Van Veen, K. (2011). Managers' awareness of fashionable management concepts: An empirical study. European Management Journal, 29(3), 206-216 